\title{
"TURUN" AS PARTICIPATORY BUDGETING PRACTICES BASED ON SIRI' NA PESSE AT THE DEATH CEREMONY IN BAEBUNTA, NORTH LUWU REGENCY, INDONESIA
}

\author{
Andi Mattingaragau Tenrigau*, Herawati Dahlan, Nur Aida \\ Universitas Fajar, Indonesia
}

\begin{abstract}
This study aims to determine participatory budgets of siri' na pesse in "turun" tradition of death events in Baebunta, Luwu Utara Regency. The study uses an interpretive paradigm with a methodological and ethnographic design of siri' na pesse. The results show that "turun" is a participation form of maega (society) in mobilizing a budget based on a sense of pesse (empathy) and siri' (shame). The budget mobilization process consists of three parts, namely planning, determining sources, and budget allocation. The first part begins with an internal meeting of the bereaved and relative families; secondly, determining the almost-equally-divided source of the budget; thirdly, the budget allocation to finance the funeral procession and the night of takziah (condolence). The activities properly show the upright siri' (self-esteem) for the bereaved family.
\end{abstract}

Keywords: Budget, Siri' Na Pesse, Ethnography, Death Ceremony

Submitted: 15 March 2021; Revised: 22 March, 5 \& 28 April 2021; Accepted: 04 May 2021

*Corresponding author :andimattingaragau@gmail.com

DOI: $10.24252 /$ minds.v8i1.20288

ISSN-E: 2597-6990

ISSN-P: 2442-4951

http://journal.uin-alauddin.ac.id/index.php/minds 


\section{INTRODUCTION}

Each region in Indonesia has its own traditions; some of them are still taking place today. This culture is preserved in the community and practiced in everyday life, especially at traditional events, childbirth, death, and other activities. This tradition has been cultured and has become the hallmark of the local community and has been preserved from time to time.

In South Sulawesi, especially in Baebunta, North Luwu Regency, it also has a tradition of mobilizing the budget (source of funds), especially for the death events. This tradition is commonly called "turun" which in its implementation involves to maega (society). The budget mobilization in the context of local wisdom is not only known in Baebunta, but has also been practiced at the central government level (ware') of the Luwu Kingdom, especially during the Islamic period (Tenrigau, 2017a). However, the term used to describe budget mobilization is solo' or massolo'.

"Turun" is a form of participatory budget mobilization carried out by people living in Baebunta and its surroundings to ease the burden when a family member, neighbor, or social group dies. All community members voluntarily visit the funeral home by bringing various substantial objects and funds needed for the implementation of the funeral procession.

The term "turun" is generally used by people in the Baebunta area and its surroundings to show an attitude of pesse (empathy). Pesse means feeling the suffering of others in one's own body (heart/feeling), indicating a deep feeling of compassion (empathy) towards neighbors, relatives, or fellow social group members (Pelras, 2006). The existence of pesse here shows people's caring attitude as a form of their inner participation towards others.

In the cultural context, especially the Makassar Bugis, Pelras (2006) considers pesse as a buffering attitude for the sustainability of community life. This view shows that pesse is a deep feeling of empathy for those who are grieving because of illness or being hit by natural disasters. Research conducted by Tenrigau (2020 et al.,) in Masamba, North Luwu Regency, shows a sense of siri' na pesse in responding to the large number of victims who died as a result of the flood disaster. As a form of deep feeling (pesse), people from various regions provide various types of assistance to reduce the suffering experienced by residents due to lack of budget.

The assistance provided by the local community in accounting or financial terms is basically a term of the budget itself. Referring to Garrison, Norren, and Brewer (2007), it is clear that a budget is a detailed plan regarding the acquisition and use of financial resources and other resources during a certain period of time. This shows that basically the budget concept understood by the Baebunta community and in terms of accounting or finance is the same. The difference only lies in two aspects, namely the duration of time and the form of the budget. In terms of time duration, the Baebuta community does not use the term one year to denote a budget period but focuses on events. Whereas in an accounting or financial context, the budget is intended for the duration of one period or one year. Likewise in the form of a budget, in the understanding 
of the Baebunta community that any assistance in the form of objects (concrete) is considered a balanca (budget) while in accounting or finance, the budget is calculated based on monetary value.

Basically, balanca in terms of Baebunta society and in terms of accounting have the same substance. The budget is the source and use of resources in the form of numbers or monetary value (Cristina et al, 2002), whereas in the context of community traditions in Baebunta, the budget is understood as balanca, namely the various needs needed to finance an activity in the form of goods and money (cash).

Balanca in the form of tangible objects and money (cash) is a form of budget needed to finance an activity, especially in the procession of the death ceremony in Baebunta. The donation donated by to maega (community) is a form of pesse (empathy) as spiritual tolerance to grieving families and an effort to raise siri' (dignity) in overcoming budget (balanca) problems. In connection with this, this research is basically to determine the participatory budget for the death event based on Siri 'na pesse at the death ceremony in Baebunta, North Luwu Regency.

\section{THEORETICAL REVIEW}

\section{Limitations and Types of Budget}

The word of budget is derived from the French word of bougetter which means a small bag or one small upper (Arif et al., 2009). This definition then developed, as defined by The National Committee on Government of the United States that budget is an activity plan measured in units of money which contains an estimate of expenditure in a certain period and the source proposed to finance the expenditure. Basically, the budget includes three things, namely planning, revenue (sources), and expenditure.

The budget consists of several types, one of which is cash. In another limitation, the budget is not only measured in financial units, but also in other forms (Garrison \& Brewer, 2007) which in this context can be understood as anything that has economic value that can be measured in monetary value based on market prices.

\section{Local Wisdom-Based Budgets}

In the Luwu Ana' Tellue language, the budget term refers to the term balanca, namely the sacrifice of resources to obtain goods or services (Tenrigau \& Said, 2017a). During the Kedatuan (kingdom) of Luwu era, the balanca term was used to denote the number of resources used for consumption or use in a customary activity, death, birth, or family or personal needs. Generally, it is in the form of foodstuffs or in other forms needed in an activity such as "turun" event.

In terminology, the word "turun" is defined as an activity to provide materials needed for an activity such as a traditional event, death, or childbirth. In the local wisdom context, these goods or activity needs are called balanca or 
budget (revenue/source). This type of balanca (budget source) is the most popular for people in Baebunta in mobilizing resources.

\section{Terminology and Philosophy of Siri' na Pesse}

Budget participation that is carried out to maega (society) to assist in these activities is based on values and a sense of siri' na pesse. Etymologically, siri' na pesse consists of two words, namely siri' and pesse. In the Luwu Bugis language, siri' means shame. If it is used in a particular context, siri' can also be interpreted as self-esteem (Mattulada, 2005) or a driving force for development (Lopa, 2005). In terminology, siri' is an effort to maintain dignity both as individuals and as a broader community group (Tenrigau et al., 2017b).

The word of pesse in the Bugis Luwu language is pedis. Other terminology defines pesse as a sense of empathy (Andaya, 2004), people's mood (Hamid, 2005), feelings of compassion or empathy (Pelras, 2006), or spiritual tolerance. In terminology, pesse is a feeling of empathy or spiritual tolerance to the downturns experienced by society.

Siri' na pesse can be used in any situation depending on the context. If it is related to local wisdom-based budgets, the use of the term siri' na pesse is appropriate because it relates to people's attitudes and behavior in budget mobilization to ease the burden or cost of activities in society.

\section{METHODOLOGY}

This study used an interpretive paradigm. Interpretive paradigm is a social system that interprets behavior in detail, sees phenomena, and explores experiences from the object of research (Neuman, 2003), and tries to understand individual social actions at the level of meaning that binds every human being (Agger, 2003).

On the other hand, the approaches used are the methodological and ethnographic siri' na pesse. The methodological siri' na pesse is the study of science or methods of adversity cases or problems faced by social class people who need to overcome the problems they are facing (Tenrigau, 2020). The focus of this method discusses the social conditions of the community that experience helplessness, adversity, poverty as a result of an event or policy that occurs.

The use of the pesse na siri' method is based on two things. The first is the condition of adversity (pesse) felt by the grieving families to which the local community responds to feel a deep spiritual atmosphere. The second is maseddisiri' (unity of shame) which is built by the local community so that they voluntarily and unite to help others as an expression of the spiritual atmosphere felt by a bereaved family.

Meanwhile, the ethnographic approach assumes that a researcher makes conclusions beyond what is seen or said explicitly from what is meant or implied. In other words, the observation is not carried out on the surface but is carried out by an in-depth study. This is in line with Clifford Geertz's point that an important part of ethnography is a rich description, specific explanations, and details (Neuman, 2003). 
The use of the method is to see the broad or coverage of the community in addressing the budget problems faced by the bereaved family. This means that budget participation is seen not only as one person but also in the wider community.

The research was conducted from September 2020 to April 2021. Information gathering was carried out through observation and interviews. The observation was carried out at the funeral home by observing how the people in Baebunta carried out a budget mobilization based on siri' na pesse to meet the needs of grief activities. Meanwhile, interviews were conducted with bereaved families, communities, and people who were well acquainted with the "turun" tradition.

Data analysis was carried out in three stages. The first is continuity analysis which was conducted from the start, medium, and the completion of the collection process. The second is interpreting documents/data based on interviews and observations to obtain general meaning. The third is to make a specific and in-depth interpretation which begins with grouping themes related to budget participation which are the key themes, especially from the results of interviews and observations.

\section{RESULTS AND DISCUSSION}

Baebunta is one of the customary governments, i.e., ana' tellue (at the provincial level) during the reign of Luwu kingdom. Even though this absolute monarchy government has joined the Unitary State of the Republic of Indonesia (NKRI), this region still has many traditions which are still practiced until now; one of them is "turun".

"Turun" is a form of participation in mobilizing the budget (balanca) which is carried out to maega (society) to ease the burden on those who carry out an activity, for example at traditional events, grief, childbirth, or others (Coville, 2020). In contrast to activities such as plowing the fields, planting, harvesting, or other private activities are not included in this framework. Thus, to maega (society) does not have a social obligation to get involved.

When a family member dies, the first step taken by the bereaved is to convey the news of grief in two ways, namely in public places and from house to house or person to person (face to face). The new is informed in public places, including through mosques (houses of worship), meeting halls, or other places where people are thronged. Meanwhile, the second method is from house to house, either to close family or neighbors or when meeting people accidentally (Adams, 1993).

This information is a benchmark of to maega (society) to conduct "turun". Those who have received the news, immediately prepare the materials needed by the bereaved family as a source of budget (balanca) for the implementation of the activities. The budget process in implementing a series of death events consists of three parts, namely planning, resources, and expenditure.

The first part is planning. In this section, the bereaved family invites close relatives to conduct an internal meeting to plan a series of activities 
including the required funeral time, takziah, and budgeting (balanca). One of the basic considerations for budgeting (balanca) is the length of activity days associated with the takziah (condolence/sympathy) implementation time. Takziah activities are condolences to entertain the bereaved family through Islamic lectures that are held at night. The implementation can be done on the first night, the third night, the seventh night, or the first night until the third or the first night until the seventh night.

Although the duration of the activity varies, in general, the community conducts "turun" only once. If the takziah is carried out on the first night, then the "turun" event is held in the afternoon. If it is done on the first night until the third night or the third night only or until the seventh night, then "turun" event is conducted on the third day leading up to the third night. When deciding to conduct takziah, that is when a budget is arranged. First of all, predicting the amount of budget needed by first taking into account the "turun" contribution experience. From the previous experience, "Turun" is in the form of money (cash) and foodstuffs (consumer goods) which are about 35\% of the total budget. Thus, the rest budget is borne by the bereaved and relative families (Hasbi et al., 2019).

The second part is sources of funds (resources). Based on the results of the meeting, the bereaved family offered to close relatives to donate based on their respective sincerity and abilities. Some of them donated money, groceries, as well as in other forms. Based on the experience in Baebunta, Luwu Utara Regency, the budget needs for grief are divided into three parts: the bereaved family bears approximately 35\%, close family is 30\%, and "turun" is 35\%.

The involvement of to maega (society) in the death events is a form of social responsibility as part of the society members. The act of helping others is based on a feeling or value of pesse (empathy) in their heartstrings. The feeling of pesse is a form of concern for the spiritual atmosphere experienced by a member of society who is grieving. The local people really understand and feel a deep spiritual atmosphere so that they sincerely conducted "turun" together to come to the funeral home. They bring various needs for the event, including money (cash), rice, sugar, flour, cooking oil, eggs, butter, and other supporting groceries.

The cash or money is used to buy various necessities for events such as side dishes, spices, transportation costs, as well as other main and supporting needs. On the other hand, donations in the form of rice, flour, sugar, butter, eggs, and cooking oil are used to provide food and various snacks for the morning, afternoon, and evening for guests during the mourning period. 


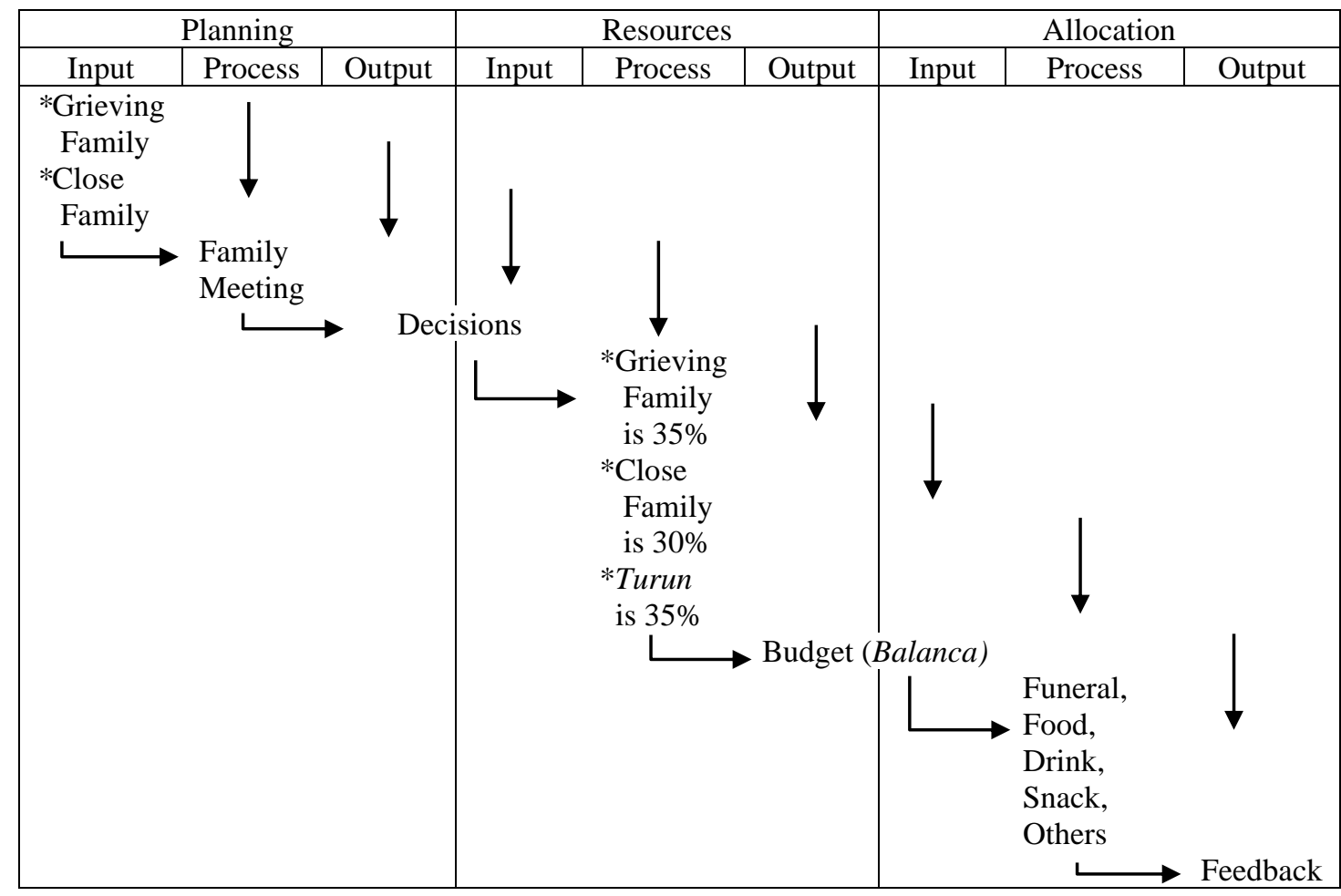

Figure 1. Planning, Resources, and Budget Allocation for the Death Event

The various donations given by to maega (society) are a form of active participation in mobilizing the budget (balanca) to meet grief costs. Participation is a form of society participation based on a sense of pesse (empathy), while mobilization is a conscious act of mutual understanding together to collect the various materials needed. Mobilization is not directed by a person or a party but a shared awareness to help each other to implement "turun" by bringing or providing the various needs that are needed.

Contributions in various forms have an economic value which, if it is counted, is quite a lot. In absolute terms, the amount of "turun" donations is around $35 \%$ and in some places, the value is sometimes even greater.

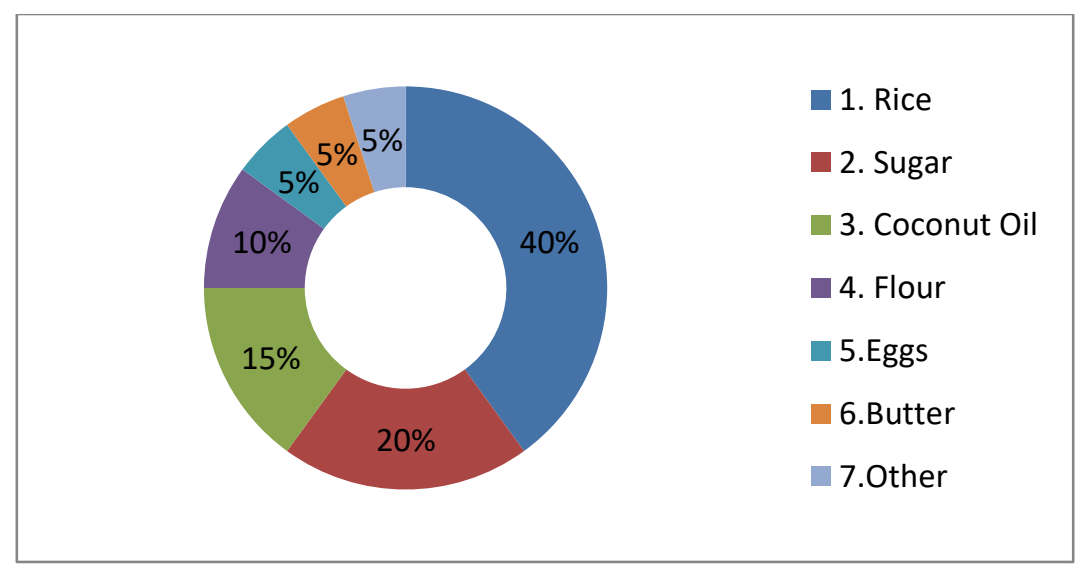

Source: Interviews with various informants, data calculated (2020)

Figure 2. The Percentage of Various Types of "Turun" Donations 
If it is described based on the percentage of the type of "turun" donation, then based on the economic value, the order is rice $40 \%$, sugar $20 \%$, coconut oil $15 \%$, flour $15 \%$, eggs $5 \%$, butter $5 \%$, and others $5 \%$. This donation does not include cash. Based on this result, it shows that the contribution or donation is more dominant for the needs of groceries needs (e.g., food, drinking, and snack). Thus, the society responds based on the needs of these activities.

The third part is the expenditure or the budget use. This section represents the use of all resources in the form of money (cash) and groceries. These resources are used for funeral expenses, takziah on appointed nights, and other expenses.

After the whole series of death ceremonies have been completed, the bereaved family and relative family check whether the resources received are used up or if there are still remaining. From the existing experience (Tenrigau, 2017a), generally, the incoming donations are not used up. Thus, money (cash) and especially donations from "turun" are given to people who work (feedback) during a series of events. It can be said that the awarding is a form of conversion of labor costs for services provided during the activity, even though in essence they do not expect this return.

The implementation of activities properly is a form of mammesa siri' or maseddi siri' (unity of shame). When society unites in the success of the death series through participation in budget mobilization ("turun"), it is essentially said that the siri' (shame) of the bereaved family has been restored or lifted.

\section{CONCLUSION}

The "turun" activity is the participation of to maega (society) in mobilizing the budget as an expression of condolences at the death ceremony in Baebunta, North Luwu Regency. As a tradition, when there is a death, a series of activities are held from funerals to performing takziah for Muslims.

The budget process in implementing those activities consists of three parts, namely planning, determining the source of funds, and their use. The planning section began with an internal meeting of the bereaved and close/relative families. The substance of the meeting discusses the time of the funeral, the determination of the night of takziah, the source and use of funds. Based on the experience of several previous activities, the number of costs borne by the bereaved family was around 35\%, relative family was 30\%, and "turun" was 35\%.

The second part is determining the source of funds (balanca). In this section, the bereaved family asked the relative family's willingness to donate and accept the participation of "turun" donations from to maega (society) in the form of money (cash), groceries (e.g., rice, sugar, flour, eggs, butter), and other supporting materials.

The third part is the use of funds. All collected donations are distributed to each series of activities including paying for the funeral and the night of the takziah. After the activity is completed, a calculation of the remaining cash and other groceries would be calculated. If there was any remaining, then it was distributed to the people who help work as a form of gratitude. 
The "Turun" tradition is a form of pesse (empathy) of to maega (society) to the grieving parties as a form of mammesa siri' or massedi siri (unity of shame). If a series of events for death is not carried out properly due to a lack of balanca (funds or budgets), then it is considered as siri' (shame) for the grieving families, which in the end is also condemned to maega (society) because they are a unity (mammesa/masseddi) in a large family whose name is public. In other words, the proper implementation of activities are a prizing form of siri' (dignity) for the grieving family.

\section{REFERENCES}

Adams, K. M. (1993). Club Dead, Not Club Med: Staging Death in Contemporary Tana Toraja (Indonesia). Southeast Asian Journal of Social Science. https:/ / doi.org/10.1163/030382493x00116

Agger, B. (2003). Teori Sosial Kritis: Kritik, Penerapan, dan Implikasinya. Yogyakarta: Kreasi Wacana.

Andaya, L. Y. (2004). Warisan Arung Palakka: Sejarah Sulawesi Selatan Abad Ke17. Makassar: Ininnawa.

Arif, B., Muchlis, \& Iskandar. (2009). Akuntansi Pemerintahan. Jakarta: Akademia.

Cristina, E., Fuad, M., Sugianto, \& Sukarno Edy. (2002). Anggaran Perusahaan. Jakarta: PT Gramedia Pustaka Utama.

Coville, E. (2020). Remembering our dead: The care of the ancestors in tana toraja. In The Potent Dead: Ancestors, saints and heroes in contemporary Indonesia. https:// doi.org/10.4324/9781003118176-5

Garrison, N. \& Brewer. (2007). Akuntansi Manajerial. 11 th edition. Jakarta: Salemba Empat.

Hamid, A. (2005). Kepercayaan dan Upacara dari Budaya Bugis Kuno, in Nurhayati Rahman, Anil Hukma, dan Idwar Anwar (ed) Laga Ligo: Menelusuri Jejak Warisan Dunia. Makassar, Pusat Studi Laga Ligo Divisi Ilmu Sosial dan Humaniora Pusat Kegiatan Penelitian Unhas.

Coville, E. (2020). Remembering our dead: The care of the ancestors in tana toraja. In The Potent Dead: Ancestors, saints and heroes in contemporary Indonesia. https:/ / doi.org/10.4324/9781003118176-5

Hasbi, Sukimi, M. F., Latief, M. I., \& Yusriadi, Y. (2019). Compromise in traditional ceremonies: A case study of the Rambu solo' ceremony in Toraja regency. Humanities and Social Sciences Reviews. https:// doi.org/10.18510/hssr.2019.7651

Lopa, B. (2005). Siri Dalam Masyarakat Mandar. Dalam Siri' dan Pesse: Harga Diri Bugis, Makassar, Mandar, dan Toraja. $2^{\text {nd }}$ edition. Makassar: Pustaka Refleksi.

Neuman, W. L. (2003). Social Research Methods: Qualitative and Quantitative Approache. Boston: Allyn and Bacon.

Mattulada. (2005). Siri' dalam masyarakat Makassar. In M.Y. Mustafa, A. Nasyaruddin, \& A.W. Tangke, Siri' dan pesse: harga diri Bugis, Makassar, Mandar, dan Toraja, 2nd Edition. Makassar: Pustaka Refleksi. 
Pelras, C. (2006). The Bugis. Translator Abdul Rahman Abu, Hasriadi, dan Nurhadi Sirimorok. Jakarta: Nalar dan Forum Jakarta Paris.

Tenrigau, A. M., Dahlan, H., Uleng, B. P., \& Aida, N. (2020). Penganggaran Berbasis Kearifan Lokal: Studi Siri' Na Pesse Metodologi Pada Program Desa Mengepung Kota Di Kabupaten Luwu Timur. Jurnal Ilmiah Administrasi Publik PKP2A LAN Makassar, 14 (2), 91-98.

Tenrigau, A. M. \& Said, D. (2017a). Pesse Na Siri' Budgetary System: A Historiography Study of Luwu Kingdom in Islamic Period. Journal of Research in Humanities and Social Science, 5 (8), 58-65.

Tenrigau, A. M., Triyuwono, I., Said, D., \& Damayanti, R.A. (2017b). Reconstruction of Pesse na Siri' Budgeting Consept: A Posmodernism Study in East Luwu Regency. International Journal of Science and Research, 6 (5), 216-222. 